\title{
Description of a new species of Caccoleptus (Coleoptera: Dermestidae) from Brazil
}

\author{
R. S. Beal, Jr. (")
}

\begin{abstract}
A new species of dermestid beetle, Caccoleptus honeymani, is described, the first known member of the genus from Brazil. Notes are given on another Brazilian species of the genus, which is not formally named at this time.

The genus Caccoleptus as presently recognized consists of 2 species from Central America and one species from Colombia, Guyana, and Panamá. Little is known of members of the genus except that larvae and adults of $C$. wicki Beal in Colombia are predators on eggs and first instar larvae of Opsiphanes cassina F., a nymphalid butterfly defoliator of banana plants (Beal, 1978). Shortly after I completed a review of the genus in 1978, 1 found a few specimens of 2 additional species in material collected in Brazil by Herbert H. Smith and deposited in the collection of the Carnegie Museum of Natural History. One of the 2 species, although represented by only 5 specimens, is being described at this time because of interest in members of the genus as possible agents of biological control.

I take pleasure in dedicating the species to Dr. Robert B. Honeyman, Jr., of San Juan Capistrano, California, a student of the history and literature of science.
\end{abstract}

\section{Caccoleptus honeymani, new species}

ADULT MALE - Habitus as illustrated (Fig. 1). Dorsal pubescence of long, suberect, brown hairs, shorter subrecumbent brown hairs, and subrecumbent ensiform white hairs; longest suberect brown hairs about $1 / 2$ as long as width of interocular space; white hairs about half length of longest brown hairs; brown hairs distributed more or less uniformly over dorsal surface; white hairs in irregular pat-

(*) - Northern Arizona University, Flagstaff.

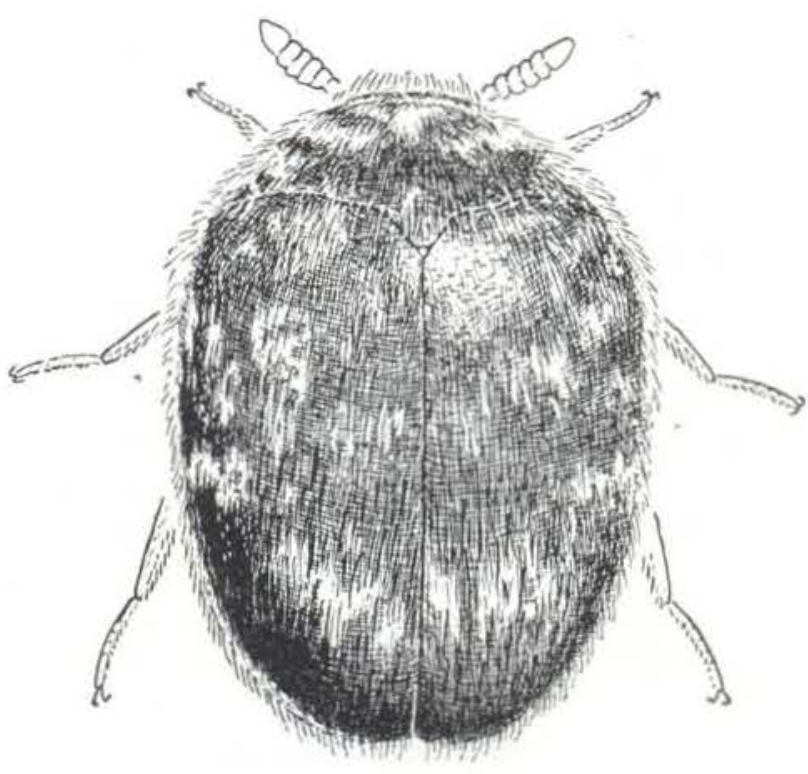

Fig. 1 - Caccoleptus honeymani $\hat{\delta}$, dorsal aspect.

ches but patches of elytra mostly on submedian and subapical areas. Head with integument dark reddish brown. Ratio of width of interocular space to width across compound eyes 1:1.94. Punctures of vertex simple, equal in diameter to $1 \frac{1 / 2}{2}$ times diameter of facet of compound eye and separated by 1 to 2 times diameter of single puncture. Antenna ochreous with 8-segmented club; segment 4 about 2 times as wide as segment 3 ; club not pectinate (pedicels inserted near center of segments). Pronotum with integument rubiginous except for suffused fuscous area on disc; punctures of disc simple with punctures equal in diameter to 1 to $1 \frac{1}{2}$ diameters of compound eye; punctures separated by 1 to 3 times dia. meter of smaller punctures. Elytra with integument fuscous with suffused rubiginous maculae; maculae forming basal circle, short submedian band, and subapical band; submedian 
band close to and somewhat coalescing with posterior margin of basal circle. Thoracic sterna with integument fuscous on sides becoming rubiginous medially. Antennal fossa occupying all of hypomeron except for small convexly rounded triangular area adjacent to compound eye; posterior margin enclosed entire length by knife-like carina. Prosternal process moderately broad, about $12 / 5$ times as broad at level of hind margin of front coxa as width of front tibia. Mesosternum on each side of median sulcus somewhat oblique and about half as long as wide. Abdominal sterna with integument rubiginous. Sternum of (morphological) segment 8 as illustrated (Fig. 2A). Aedeagus and lateral lobes as illustrated (Fig. $2 \mathrm{C}$ ); length of aedeagus not exceeding length of lateral lobes; base furcate with more or less square flange extending dorsad between lateral lobes from point of furcation; apex with minute proximally directed hook on dorsal side. Lateral lobes with relatively long apodeme at base; medial extensions of lateral lobes (which in other species of Megatomini form a bridge between the lobes) present, not joined at midline but near midline curving toward ba. se. Legs ochreous. Ratio of width (measured across humeri) to length (of pronotum and elytra combined) $1: 1.45$. Length (of pronotum and elytra combined): $2.16 \mathrm{~mm}$.

RANGE OF OBSERVED VARIATIONS - Color of integument of pronotum and elytra as described above to entirely rubiginous except for suffused, slightly darker areas on elytra at center of basal circles and at middle. Elytra with patches of white pubescence forming prominent subapical band but otherwise quite irregular. Ratio of length (of pronotum and eiy. tra) to width (across humeri) varying from $1: 1.35$ to $1: 1.45$. Lengthe ranging from 2.16 $\mathrm{mm}$ to $2.52 \mathrm{~mm}$.

HOLOTYPE MALE - Chapada, Brazil, Novem. ber (deposited in the collection of the Carnegie Museum of Natural History). Paratypes, all males, as follows: Taperina, Brazi!, June; same locality, no date; Corumbá, Brazil, no cate: Santarem, Brazil, no date. Although the specimens above do not include a collector's label, records in the Carnegie Museum of $\mathrm{Na}$ -

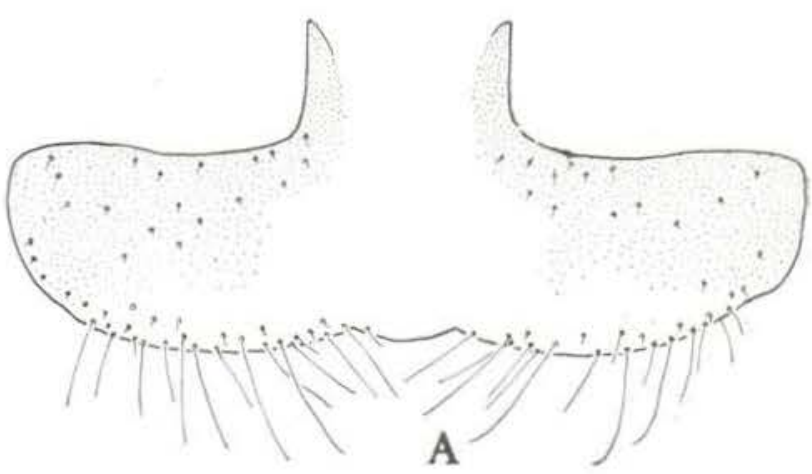

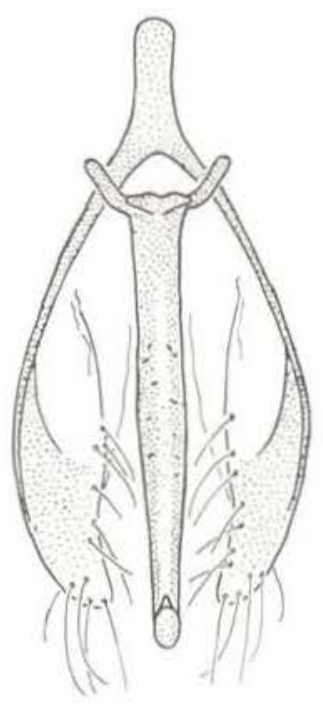

B

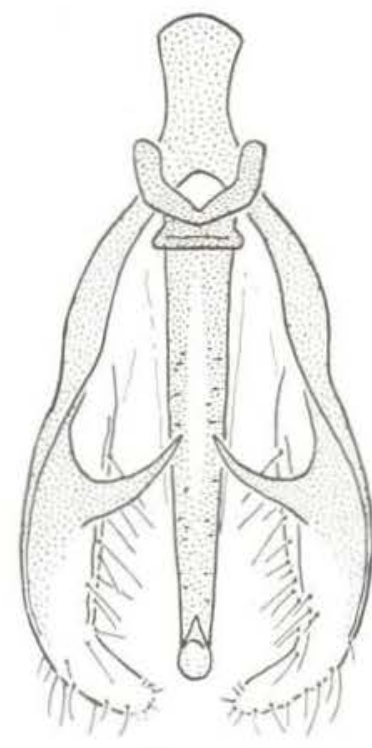

C
Fig. 2 - Male genital structures, A: Sternum of morphological abdominal segment 8 of C. honeymani. B: Lateral lobes and aedeagus of undescribed species of Caccoleptus. C: Lateral lobes and aedeagus of C. honeymani.

tural History that correspond with the museum accession number on the specimens indicate that they are part of a collection purchased from Herbert H. Smith in 1906 and presumably collected by him (George Wallace, in litt.). Paratypes deposited in the U. S. National Museum of Natural History, Instituto Nacional de Pesquisas da Amazonia, and the collection of the author.

Chapada, the type locality, is approximately $40 \mathrm{~km}$ (25 miles) ENE of Cuiabá, the capital of the state of Mato Grosso. Collections designated with this locality were taken by Smith both near the village at an elevation of $760 \mathrm{~m}$ 
and in the surrounding regions to elevations as low as $550 \mathrm{~m}$ (Calvert, 1909). The real name of the village, according to Smith, is Santa Anna la Chapada, but on current maps it is designated Chapada dos Guimarães. Smith collected here in 1885 and 1886 (Calvert, 1909). Santarém is on the amazon River at its junction with the Tapajós River. Taperina is no doubt an alternative spelling for Taperinha, a plantation on the Amazon $32 \mathrm{~km}$ downstream from Santarém (Smith, 1879, p. 152). According to Holland (1919), Smith began his explorations of the Amazon in 1874 and continued collecting along its tributaries for the ensuing 3 years.

C. honeymani is readily distinguished from the only other described South American species, C. wicki, by the presence of spot-like clusters of white hairs on the elytra. C. wicki, known from the vicinity of Cúcuta in northeast Colombia and Georgetown, Guyana, is covered dorsally with light golden and dark brown to piceous hairs. The golden hairs of $C$. wicki form a broad submedian and an apical band. In addition, some specimens have a basal extension of the submedian band along the median suture. There may or may not be a short basal band. The irregular pattern of white patches of hair on C. honeymani contrasts strongly with this. C. honeymani may be distinguished from the 2 known Central American species, C. anisotomoides Sharp and C. rotundus Sharp, by the shape of the antennal fossa. In the Central American species the anterior wall of the fossa is concave its entire length, including the medial margin next to the head. In C. honeymani there is a small but distinct triangular convexity on the anterior wall of the antennal fossa next to the head.

\section{Caccoleptus species unnamed}

The other Brazilian species of Caccoleptus taken by Smith is represented by 2 specimens from a locality designated as Entre Rios. The badly abraded condition of the specimens precludes their formal description at this time. The species is distinguished from C. honeyma$n i$ and $C$. rotundus by the pectinate antennal club of the male, by the length of th aedeagus, which exceeds the length of the lateral lobes, and by the lack of any suggestion of a bridge connecting the lateral lobes. Although there is more than one Brazilian locality named Entre Rios, this is said to be "on a branch of the Dom Pedro Segundo Railroad, where the latter meets the União e Industria road" (Smith, 1879). No locality named Entre Rios with such a description appears on current maps. The locality must, nevertheless, be in the general vicinity of Além Paraíba.

It is worth noting that the lateral lobes of both $C$. honeymani and the unnamed species listed above lack a sclerotized median connection. All other species of Megatomini for which the genitalia have been examined, with the exception of some species of Anthrenus (e.g., A. tadzhicus Mroczkowski, 1961), have a well-developed submedian bridge between the lobes. In C. honeymani (Fig. 2C) there is a partially formed bridge. The unnamed species lacks any indication of a bridge (Fig. 2B).

\section{ACKNOWLEDGEMENTS}

I wish to acknowledge the generosity of George E. Wallace of the Section of Insects and Spiders of the Carnegie Museum of Natural History for making these specimens available for my study and directing my attention to literature describing the collecting cotivities of H. H. Smith.

\section{Resumo}

Uma nova espécie de dermestídeo, Caccoleptus honeymani, é descrita e comparada com três outras espécies conhecidas. Somente existia uma outra espécie sul americana, C. wicki da Colômbia e Guiana. C. honeymani pode ser diferenciado deste pela presença de um agrupamento de pubescência branca na superficie dorsal e pela presença de uma área pequena convexa triangular na parede anterior da fossa antenal na margem mediana. C. wicki nảo tem pêlos brancos no dorso mas na elitra tem duas faixas de pêlo dourado. A parede anterior da fossa antenal da fêmea de C. wicki (o macho desta espécie é desconhecida e é presumida reproduzisse partenogenicamente) e côncava no seu comprimento total. Uma segunda espécie de Entre Rios, perto do Rio de Janeiro, está listada mais permanece sem nome devido ao pobre estado dos dois exemplares disponiveis. O macho desta espécie é diferenciável do macho de C. honeymani pela sua antena pectinada clavifomis. O clava da antena de C. ho- 
neymani tem os pedicelos dos segmentos perto do centro. Espécies de Caccoleptus sâo de interesse presentemente pelo seu possivel uso de controle biológico. C. wicki tem sido encontrado predando ovos e primeiros estágios larvaís de Opisphanes cassina Fabr., uma lepitóptera ninfálida, defoliadora de bananeiras.

\section{REFERENCES}

BEAL, R.S., JR.

1978 - Review of the Neotropical dermestid beetle genus Caccoleptus with description of a new species. Proc. Entom. Soc. Washington, 80 (2): 171-178.
Calvert, Philip P.

1909 - Contributions to a knowledge of the Odonata of the Neotropical region, exclusive of Mexico and Central America. Ann. Carnegie Museum, 6 (1): 73-280, Plates I-IX.

Holland, W.J.

1919 - Herbert Huntingdon Smith. Entom. News, 30 (8): 211-214.

SMith, Herbert $\mathrm{H}$.

1879 - Brazil, the Amazonas and the Coast (Charles Scribner's Sons, New York) 644 p.

(Aceito para publicação em 29/03/79) 